\title{
SMGrøup
}

\section{SM Otolaryngology Subglottic Lobular Capillary Hemangioma: A Case Report}

\author{
Vinh Ly Pham Hoang ${ }^{1}$, Nguyen Pham Dinh ${ }^{1}$, Hoang Nguyen ${ }^{2 \star}$, Joseph P \\ Kitzmiller ${ }^{2}$, Linh Bui Doan Hai ${ }^{1}$ and Huy Nguyen The ${ }^{1}$ \\ ${ }^{1}$ Department of Otorhinolaryngology, Children Hospital I, USA \\ ${ }^{2}$ Department of Biological Chemistry and Pharmacology, The Ohio State University, USA
}

\section{Article Information}

Received date: Jul 14, 2017

Accepted date: Jul 26, 2017

Published date: Jul 31, 2017

\section{${ }^{*}$ Corresponding author}

Hoang Nguyen, Department of Biological Chemistry and Pharmacology, The Ohio State University, College of Medicine, Columbus, Ohio, USA,

Email: Hoang.Nguyen@osumc.edu

Distributed under Creative Commons CC-BY 4.0

Keywords Lobular capillary hemangioma; Subglottic; Pyogenic granuloma; Coblator

Article DOI 10.36876/smotol.1008

\section{OPEN ACCESS}

\section{ISSN: 2574-2418}

\section{Abstract}

Lobular Capillary Hemangioma (LCH) is a benign proliferation of capillary blood vessels adopting a lobular configuration. A laryngeal origin of LCH is exceedingly rare. Here, we describe a case of an 11-year-old boy presenting with a subglottic lesion, leading to a subglottic stenosis. Histopathologic findings of the lesion implicated an LCH, which was removed successfully by a coblator. This is the first report of a subglottic LCH. Physicians should be aware of this unique lesion and laryngeal LCH should be considered in diagnosing the cause of a subglottic stenosis. Additionally, coblation should be an effective treatment for laryngeal LCH.

\section{Introduction}

Lobular Capillary Hemangioma (LCH), also known as pyogenic granuloma, is a benign proliferation of capillary blood vessels adopting a lobular configuration [1]. The term 'pyogenic granuloma' is a misnomer as the lesion does not contain purulent material and is not a granuloma. $\mathrm{LCH}$ is a smooth or lobulated red lesion on a sessile or pedunculated base that varies in size from a few millimeters and rarely exceeds $2.5 \mathrm{~cm}[2,3]$. The usual sites for this tumor are the skin and the nasopharyngeal and oral mucosal surfaces [4]. LCH in the gastrointestinal tract has also been reported [5]. LCH lesions are very rare in the airway, with only a few cases reported to date [6-23] and subglottic LCH is unique. Here, we present the case of an 11-year-old boy who presented with a subglottic LCH, posing both a diagnostic and therapeutic challenge.

\section{Case Report}

An 11-year-old Vietnamese boy presented to the Department of Otolaryngology, Children Hospital I, Ho Chi Minh City, Vietnam, with a complaint of dyspnea and dry coughing. He had been suffering from increasing dyspnea, coughing, and occasional wheezing for two weeks but had not been suffering from hoarseness or fever. He had no history of previous intubation, airway surgery, trauma, or tuberculosis.

Clinical examination of lung and heart revealed no abnormalities. Consequently, a neck and chest Computed Tomography (CT) with intravenous contrast was performed, which did not reveal any parenchymal lung disease. However, we observed a lesion on the left and posterior wall of the larynx, which probably caused a subglottic stenosis leading to dyspnea, wheezing, and coughing in this patient (Figure 1).

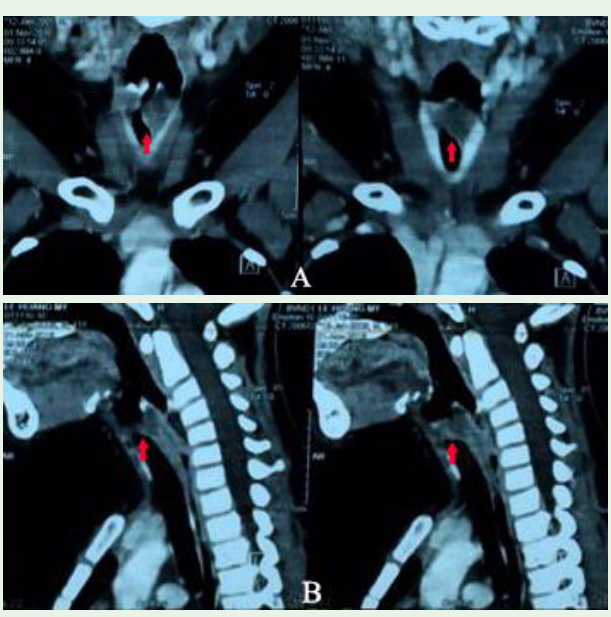

Figure 1: Neck CT scan revealed 2-cm diameter lesion on the left and posterior wall of the larynx (arrow). (A) Coronal image. (B) Sagittal image. 


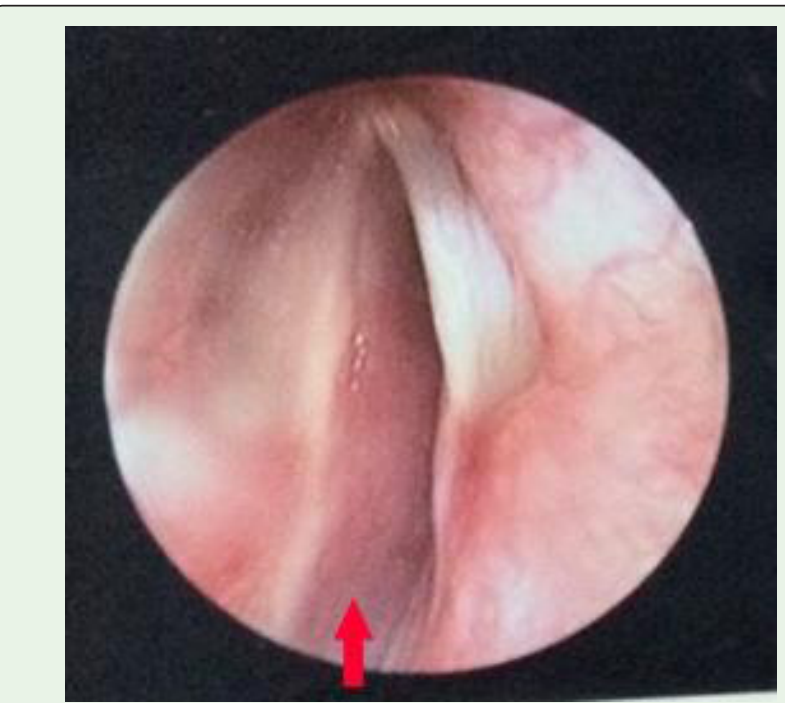

Figure 2: Laryngeal endoscopy revealed a pink soft lesion (arrow) located under the left vocal cord, leading to a grade III subglottic stenosis with a $75 \%$ obstruction.

We further performed a laryngeal endoscopy and observed a pink soft and hyperemic lesion with smooth surface located just under the surface of the left vocal cord. Consistent with the CT scan findings, the lesion was located on the left wall of the subglottic site, leading to a grade III subglottic stenosis with a $75 \%$ obstruction (Figure 2). Based on the clinical symptoms and imaging findings, a diagnosis of hemangioma was established. The patient received a tracheostomy and intravenous propanolol ( $1 \mathrm{mg} / \mathrm{kg} /$ day) for 2 weeks.

To follow up, a second laryngeal endoscopy was done. Surprisingly, the lesion grew into a firm red tumor on the left wall of the subglottic site, resulting in a grade III subglottic stenosis with a 95\% obstruction (Figure 3 ).

Aspiration of the lesion revealed no blood, and a biopsy for pathologic analysis was performed using a micro forceps. Histopathological findings of the lesion biopsy revealed a pyogenic granuloma (Figure 4) with a lobular pattern of vascular proliferation

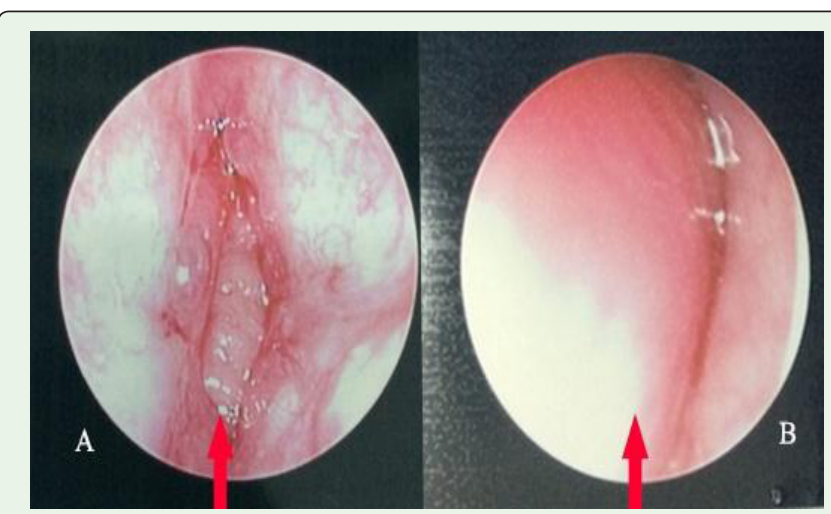

Figure 3: A second laryngeal endoscopy performed 2 weeks after the first tracheostomy revealed a firm red lesion in the left wall of the subglottic site (arrow), leading to grade III subglottic stenosis with a 95\% obstruction. Endoscopy image was taken through $(\mathbf{A})$ the patient's mouth and $(B)$ the opening of the trachea.
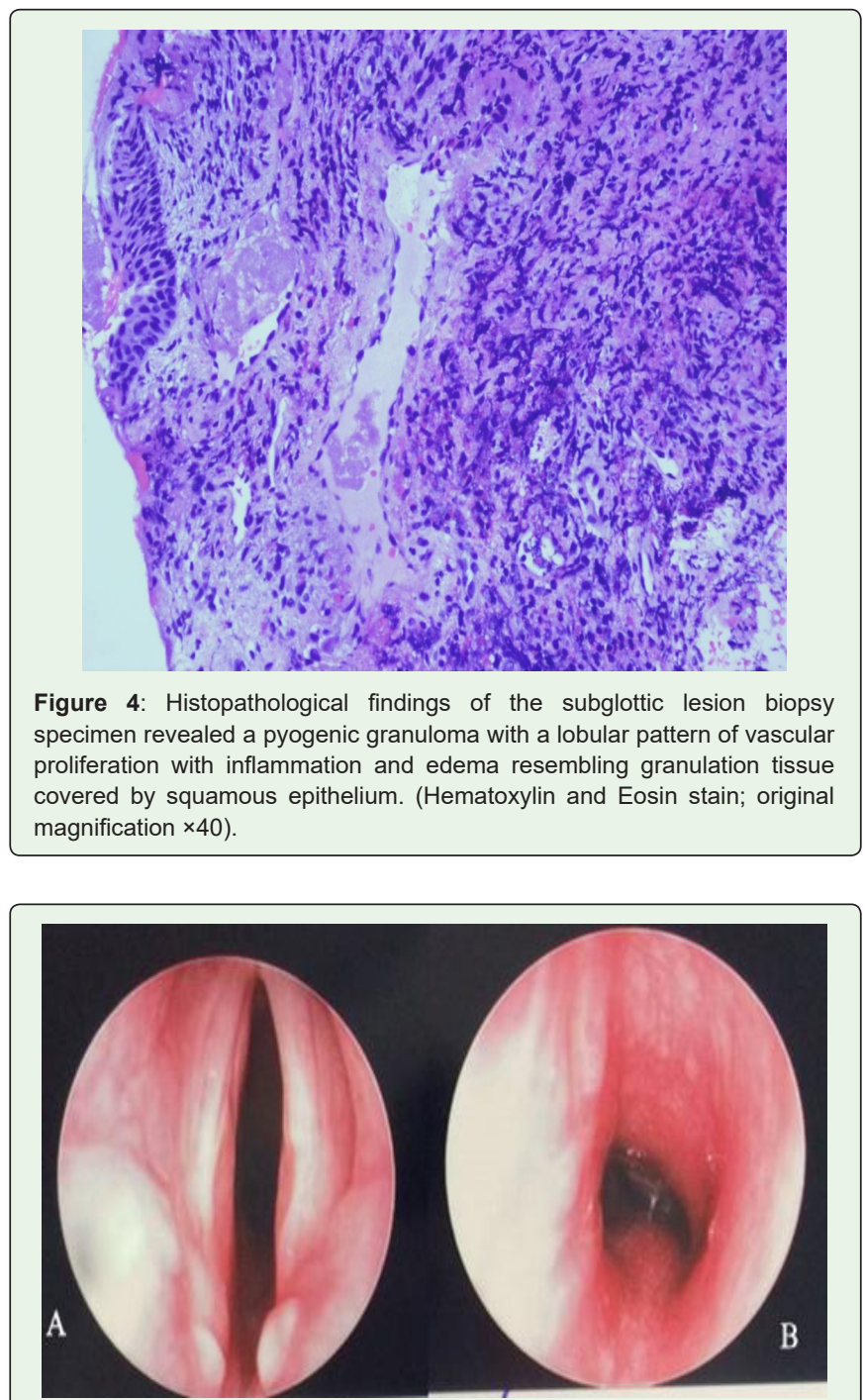

Figure 5: Laryngeal endoscopy was performed through $(A)$ the patient's mouth and $(B)$ the opening of the trachea, after 2 months follow-up. No recurrence was observed.

with inflammation and edema resembling granulation tissue covered by squamous epithelium. There was no pathological evidence of dysplasia or malignancy.

Consequently, the patient underwent an endoscopy for a complete excision of the tumor using a coblator needle-tip wand (in the coagulation mode) (Coblator II, model RE 8000E, from Arthrocare, Costa Rica 680 Vaqueros Ave, Sunnyvale CA 94085). No complications occurred during or after the procedure. The tumor specimen was sent for pathologic analysis. Histopathological findings of the specimen revealed a pyogenic granuloma. At follow-up 2 months later, a third endoscopy was performed and did not reveal any recurrent laryngeal lesion (Figure 5). The patient did not suffer from dyspnea after decannulation.

\section{Discussion}

LCH is also called Pyogenic Granuloma (PG) although it is neither induced by bacterial infection nor a true granuloma [24]. The causes 
of this disease remain unclear, and may include trauma, drug side effects, hormonal shifts, viral oncogenes, production of angiogenic factors, cytogenetic clonal deletion abnormalities, low-grade local irritation, and traumatic injury [14,15,20,24-26]. In children, $76.9 \%$ of LCH lesions appear on the head and neck, and $76.7 \%$ of those have no history of trauma or predisposing factors. Most of the manifestations are single lesions $[27,28]$.

LCH lesions are very rare in the airway, with only 18 cases reported in the trachea and the main bronchus, and 4 cases reported in neonatal vocal cords [6-23]. Table 1 summarizes all reported $\mathrm{LCH}$ cases, including the current one. However, to the best of our knowledge, LCH has not been described in the subglottic area previously.

Based on the clinical symptoms as well as the chest and neck CT and laryngeal endoscopy findings, a diagnosis of hemangioma was established first. We did not perform a biopsy during the first laryngeal endoscopy due to the high risk of bleeding of the hemangioma. The differential diagnoses of this type of lesion may include granulation tissue, tuberculosis, hemangiopericytoma, angiofibroma, angiosarcoma, and LCH. Notably, LCH located in the airways is very rare. Granulation tissue may result from an endotracheal intubation, or sometimes secondary to an inflammation

Table 1: Pyogenic granulomas cases in trachea and main bronchus.

Table 1: Pyogenic granulomas cases in trac

\begin{tabular}{|c|c|c|c|c|c|}
\hline Author & $\begin{array}{l}\text { Age, Male/Female } \\
\text { (M/F) }\end{array}$ & Location of LCH lesion & Size & Treatment & Outcome \\
\hline $\begin{array}{l}\text { Madhumita et al. } \\
\text { [10] }\end{array}$ & 40 years, $\mathrm{F}$ & $\begin{array}{l}\text { Upper third of right anterolateral } \\
\text { tracheal wall }\end{array}$ & $10 \times 5 \mathrm{~mm}$ & Endoscopic excision & Good at 1 year \\
\hline Irani et al. [8] & 72 years, $\mathrm{F}$ & $3 \mathrm{~cm}$ below vocal cords & $2-3 \mathrm{~mm}$ & Endoscopic excision & Good at 1 year \\
\hline $\begin{array}{l}\text { Amy and Enrique } \\
{[14]}\end{array}$ & 22 years, $M$ & $\begin{array}{c}3 \mathrm{~cm} \text { above carina on left posterior } \\
\text { tracheal wall }\end{array}$ & $10-15 \mathrm{~mm}$ & Electrocautery & Good \\
\hline $\begin{array}{l}\text { Porfyridis et al. } \\
\text { [13] }\end{array}$ & 17 years, $\mathrm{M}$ & $\begin{array}{c}\text { Upper third of left anterolateral tracheal } \\
\text { wall }\end{array}$ & $4 \mathrm{~mm}$ & Endoscopic excision & Good at 1 year \\
\hline Prakash et al. [7] & 23 years, $F$ & Posterior tracheal wall & $20 \times 40 \mathrm{~mm}$ & $\begin{array}{l}\text { Endoscopic excision with } \\
\text { extracorporeal membrane } \\
\text { oxygenation }\end{array}$ & Good \\
\hline Xu et al. [6] & 64 years, $M$ & Left anterolateral tracheal wall & $3-4 \mathrm{~mm}$ & Endoscopic excision & $\begin{array}{l}\text { Good at } 8 \\
\text { months }\end{array}$ \\
\hline Chawla et al. [9] & 62 years, $M$ & Distal right tracheal wall & Unknown & $\begin{array}{c}\text { Endoscopic excision and laser } \\
\text { therapy }\end{array}$ & Unknown \\
\hline Chen et al. [22] & 14 years, $F$ & Lower third of anterior tracheal wall & $15-20 \mathrm{~mm}$ & $\begin{array}{l}\text { Cryotherapy and argon plasma } \\
\text { coagulation }\end{array}$ & $\begin{array}{l}\text { Good at } 3 \\
\text { months }\end{array}$ \\
\hline $\begin{array}{c}\text { Udoji and Bechara } \\
\text { [15] }\end{array}$ & 55 years, $M$ & Distal left lateral tracheal wall & $4 \times 5 \mathrm{~mm}$ & Cryotherapy & $\begin{array}{l}\text { Good at } 3 \\
\text { months }\end{array}$ \\
\hline Putora et al. [23] & 64 years, $M$ & Distal tracheal wall & Unknown & $\begin{array}{c}\text { Spontaneous remission on cessation } \\
\text { of erlotinib for lung cancer }\end{array}$ & Good \\
\hline Acharya et al. [18] & 56 years, $\mathrm{F}$ & $\begin{array}{l}2 \mathrm{~cm} \text { below vocal cords on right } \\
\text { tracheal wall }\end{array}$ & $7 \mathrm{~mm}$ & $\begin{array}{c}\text { Endoscopic excision and } \\
\text { electrocautery }\end{array}$ & Good at 1 year \\
\hline Liu et al. [11] & 17 years, $M$ & Right wall of middle of the trachea & $5-10 \mathrm{~mm}$ & $\begin{array}{l}\text { Argon plasma coagulation, } \\
\text { cryotherapy }\end{array}$ & $\begin{array}{l}\text { Good at } 11 \\
\text { months }\end{array}$ \\
\hline Liu et al. [11] & 15 years, $F$ & Lower segment of trachea & $15-20 \mathrm{~mm}$ & $\begin{array}{c}\text { Argon plasma coagulation, } \\
\text { cryotherapy }\end{array}$ & $\begin{array}{l}\text { Good at } 6 \\
\text { months }\end{array}$ \\
\hline Qui et al. [16] & 39 years, $M$ & Right intermedius & $10 \mathrm{~mm}$ & Endoscopic excision, cryotherapy & Good at 2 years \\
\hline Walner et al. [20] & Neonatal, M & $\begin{array}{l}\text { Midportion of the right true vocal cord } \\
\text { and ventricle region }\end{array}$ & Unknown & Endoscopic excision & $\begin{array}{l}\text { Good at } 36 \\
\text { months }\end{array}$ \\
\hline Walner et al. [20] & Neonatal, F & Right true vocal cord & $\begin{array}{l}\text { Obstructing } 70 \% \text { of the } \\
\text { laryngeal inlet }\end{array}$ & Endoscopic excision & $\begin{array}{l}\text { Good at } 6 \\
\text { months }\end{array}$ \\
\hline Walner et al. [20] & Neonatal, M & $\begin{array}{c}\text { Anterior and midportion of the right } \\
\text { true vocal cord }\end{array}$ & $\begin{array}{l}\text { Obstructing } 50 \% \text { of the } \\
\text { laryngeal inlet }\end{array}$ & Endoscopic excision & $\begin{array}{l}\text { Good at } 2 \\
\text { months }\end{array}$ \\
\hline Walner et al. [20] & Neonatal, F & $\begin{array}{c}\text { Right false vocal cord and ventricle } \\
\text { region }\end{array}$ & $\begin{array}{l}\text { Obstructing } 90 \% \text { of the } \\
\text { laryngeal inlet }\end{array}$ & Endoscopic excision & $\begin{array}{c}\text { Good at } 2 \\
\text { months }\end{array}$ \\
\hline
\end{tabular}

Citation: Hoang VLP, Dinh NP, Nguyen H, Kitzmiller JP, Hai LBD and The HN. Subglottic Lobular Capillary Hemangioma: A Case Report. SM Otolaryngol. $2017 ; 1(2): 1008$

https://dx.doi.org/10.36876/smotol.1008 
of the area [12]. Nevertheless, neither recurrence nor malignant degeneration has been reported with LCH of the airways [6-23] We recommend close follow up for patients who have a history of laryngeal LCH with endoscopy as necessary.

\section{Conclusion}

To the best of our knowledge, this is the first report of unique presentation and management of a subglottic LCH. Physicians should be aware of this unique lesion and consider laryngeal LCH as a differential diagnosis of subglottic stenosis, where biopsy for histopathology could play a key role in diagnosis. Moreover, coblation was effective in treating this laryngeal LCH. Finally, further studies are necessary to understand the etiology of laryngeal LCH and ensure effective treatment for these lesions.

\section{Acknowledgement}

We thank Dr. Duy Le Pham, MD., PhD. (Faculty of Medicine, University of Medicine and Pharmacy, Ho Chi Minh City, Vietnam) for his technical support in revising the manuscript. The authors are grateful to all medical staffs, statistician of Children's Hospital I, Ho Chi Minh City, Vietnam for assistance with data acquisition. Special thanks to scientists and professors at The Ohio State University, College of Medicine, Department of Biological Chemistry and Pharmacology, Columbus, Ohio, USA for re-evaluate, recommend and validate important basic intellectual concepts correlate to clinical. The authors are also thankful for the oversight of all aspects of this case report but the Internal Review Boards (IRB) in Vietnam, as well as Department of Public Health, Board of Medicine in Vietnam. Special thanks to all the participant patients who volunteered to sign the consent and followed IRB guidelines/protocol in Vietnam.

\section{References}

1. Antonio C, Pieter JS, Nina G. Pathology of the Head and Neck $2^{\text {nd }}$ edition. Springer, 2017

2. Harris MN, Desai R, Chuang TY, Hood AF, Mirowski GW. Lobular capillary hemangiomas: An epidemiologic report, with emphasis on cutaneous lesions. J Am Acad Dermatol. 2000; 42: 1012-1016.

3. Moffatt DC, Warwryko $\mathrm{P}$, Singh $\mathrm{H}$. Pyogenic granuloma: an unusual cause of massive gastrointestinal bleeding from the small bowel. Can J Gastroenterol. 2009; 23: 261-264.

4. Fechner RE, Cooper PH, Mills SE. Pyogenic granuloma of the larynx and trachea. A causal and pathologic misnomer for granulation tissue. Arch Otolaryngol. 1981; 107: 30-32.

5. Bengi G, Solmaz D, Soyturk M, Çokbankir Ö, Yörükoğlu K. Pyogenicgranuloma in differential iron deficiency diagnosis. Turk J Gastroenterol. 2015; 26: 79-81.

6. Xu Q, Yin X, Sutedjo J, Sun J, Jiang L, Lu L. Lobular capillary hemangioma of the trachea. Arch Iran Med. 2015; 18: 127-129.

7. Prakash S, Bihari S, Wiersema U. A rare case of rapidly enlarging tracheal lobular capillary hemangioma presenting as difficult to ventilate acute asthma during pregnancy. BMC Pulm Med. 2014; 14: 41

8. Irani S, Brack T, Pfaltz M, Russi EW. Tracheal lobular capillary hemangioma: a rare cause of recurrent hemoptysis. Chest. 2003; 123: 2148-2149.

9. Chawla M, Stone C, Simoff MJ. Lobular capillary hemangioma of the trachea: the second case. J Bronchology Interv Pulmonol. 2010; 17: 238-240.

10. Madhumita K, Sreekumar KP, Malini H, Indudharan R. Tracheal haemangioma: case report. J Laryngol Otol. 2004; 118: 655-658.
11. Liu FL, Chen EG, Zhou P, Jin M, Yang L, Ying KJ. [Tracheal lobular capillary hemangioma: two case report and review of the literature]. Zhonghua Jie $\mathrm{He}$ He Hu Xi Za Zhi. 2010; 33: 849-852.

12. Jie S, Hong-rui L, Fu-quan Z. Brachytherapy for Tracheal Lobular Capillary Haemangioma (LCH). J Thorac Oncol. 2012; 7: 939-940.

13. Porfyridis I, Zisis C, Glinos K, Stavrakaki K, Rontogianni D, Zakynthinos S et al. Recurrent cough and hemoptysis associated with tracheal capillary hemangioma in an adolescent boy: a case report. J Thorac Cardiovasc Surg. 2007; 134: 1366-1367.

14. Amy FT, Enrique DG. Lobular capillary hemangioma in the posterior trachea: a rare cause of hemoptysis. Case Rep Pulmonol. 2012; 2012: 592524

15. Udoji TN, Bechara RI. Pyogenic granuloma of the distal trachea: a case report. J Bronchology Interv Pulmonol. 2011; 18: 281-284.

16. Qiu X, Dong Z, Zhang J, Yu J. Lobular capillary hemangioma of the tracheobronchial tree: A case report and literature review. Medicine. 2016; 95: e5499.

17. Kalanjeri S, Kumar A, Mukhopadhyay S, Mehta AC. Lobular Capillary Hemangioma ("Pyogenic Granuloma") of the Trachea. Am J Respir Crit Care Med. 2016; 193: 1429-1430.

18. Acharya MN, Kotidis K, Loubani M. Tracheal Lobular Capillary Haemangioma: A Rare Benign Cause of Recurrent Haemoptysis. Case Rep Surg. 2016; 2016: 6290424

19. Dabo H, Gomes R, Teixeira N, Teixeira G, Fernandes G, Magalhaes A. Tracheal lobular capillary hemangioma treated with laser photocoagulation. J Bras Pneumol. 2016; 42: 72-73.

20. Walner DL, Parker NP, Kim OS, Angeles RM, Stich DD. Lobular capillary hemangioma of the neonatal larynx. Arch Otolaryngol Head Neck Surg. 2008; 134: $272-277$.

21. Zambudio AR, Calvo MJ, Lanzas JT, Medina JG, Paricio PP. Massive hemoptysis caused by tracheal hemangioma treated with interventional radiology. Ann Thorac Surg. 2003; 75: 1302-1304.

22. Chen E, Yu X, Zhang Z. A large tracheal capillary hemangioma treated with interventional bronchoscopy. Respir Med CME. 2011; 4: 60-61.

23. Putora PM, Benz G, Rodriguez R, Brutsche M, Fruh M. Tracheal granuloma pyogenicum with erlotinib treatment for lung cancer. Eur Respir J. 2011; 38 : 1228-1230.

24. Mills SE, Cooper PH, Fechner RE. Lobular capillary hemangioma: the underlying lesion of pyogenic granuloma. A study of 73 cases from the oral and nasal mucous membranes. Am J Surg Pathol. 1980; 4: 470-479.

25. Yuan K, Wing LY, Lin MT. Pathogenetic roles of angiogenic factors in pyogenic granulomas in pregnancy are modulated by female sex hormones. J Periodontol. 2002; 73: 701-708.

26. Jafarzadeh H, Sanatkhani M, Mohtasham N. Oral pyogenic granuloma: a review. J Oral Sci. 2006; 48: 167-175.

27. Pagliai KA, Cohen BA. Pyogenic granuloma in children. Pediatr Dermatol. 2004; $21: 10-13$.

28. Lian TS. Benign tumors and tumor-like lesions of the oral cavity. Cummings Otolaryngology-Head and Neck Surgery. 4th ed, 2005.

29. Shin JE, Nam SY, Yoo SJ, Kim SY. Changing trends in clinical manifestations of laryngeal tuberculosis. Laryngoscope. 2000; 110: 1950-1953.

30. Zhao N, Sun Y, Sun Z. [Clinical analysis of the diagnosis of laryngeal tuberculosisLin Chung Er Bi Yan Hou Tou Jing Wai Ke Za Zhi. 2009; 23: 261-263.

31. Taira JW, Hill TL, Everett MA. Lobular capillary hemangioma (pyogenic granuloma) with satellitosis. J Am Acad Dermatol. 1992; 27: 297-300. 